Article

\title{
Kynurenic Acid Accelerates Healing of Corneal Epithelium In Vitro and In Vivo
}

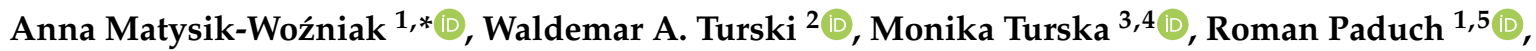 \\ Mirosław Łańcut ${ }^{6}$, Paweł Piwowarczyk ${ }^{7}$ (D), Mirosław Czuczwar ${ }^{7}$ (D) and Robert Rejdak ${ }^{1}$
}

\section{check for} updates

Citation: Matysik-Woźniak, A.; Turski, W.A.; Turska, M.; Paduch, R.; Łańcut, M.; Piwowarczyk, P.; Czuczwar, M.; Rejdak, R. Kynurenic Acid Accelerates Healing of Corneal Epithelium In Vitro and In Vivo. Pharmaceuticals 2021, 14, 753. https://doi.org/10.3390/ph14080753

\section{Academic Editors:}

Ioannis Tsinopoulos, Ioanna Mylona and Lampros Lamprogiannis

Received: 4 July 2021

Accepted: 28 July 2021

Published: 30 July 2021

Publisher's Note: MDPI stays neutra with regard to jurisdictional claims in published maps and institutional affiliations.

Copyright: (c) 2021 by the authors. Licensee MDPI, Basel, Switzerland. This article is an open access article distributed under the terms and conditions of the Creative Commons Attribution (CC BY) license (https:// creativecommons.org/licenses/by/ $4.0 /)$.
1 Department of General and Pediatric Ophthalmology, Medical University of Lublin, 20-079 Lublin, Poland; rpaduch@poczta.umcs.lublin.pl (R.P.); robert.rejdak@umlub.pl (R.R.)

2 Department of Experimental and Clinical Pharmacology, Medical University of Lublin, 20-090 Lublin, Poland waldemarturski@umlub.pl

3 Department of Pharmacology, Faculty of Health Sciences, Medical University of Lublin, 20-093 Lublin, Poland; turskamk@gmail.com

4 Postgraduate School of Molecular Medicine, Medical University of Warsaw, 02-091 Warsaw, Poland

5 Department of Virology and Immunology, Institute of Microbiology and Biotechnology, Maria Curie-Skłodowska University, 20-033 Lublin, Poland

6 Center for Experimental Medicine, Medical University of Lublin, 20-090 Lublin, Poland; miroslaw.lancut@umlub.pl

7 2nd Department of Anesthesiology and Intensive Care, Medical University of Lublin, 20-081 Lublin, Poland; piwowarczyk.pawel@gmail.com (P.P.); miroslaw.czuczwar@umlub.pl (M.C.)

* Correspondence: anna.wozniak@umlub.pl; Tel.: +48-81532-8601

Abstract: Kynurenic acid (KYNA) is an endogenous compound with a multidirectional effect. It possesses antiapoptotic, anti-inflammatory, and antioxidative properties that may be beneficial in the treatment of corneal injuries. Moreover, KYNA has been used successfully to improve the healing outcome of skin wounds. The aim of the present study is to evaluate the effects of KYNA on corneal and conjunctival cells in vitro and the re-epithelization of corneal erosion in rabbits in vivo. Normal human corneal epithelial cell (10.014 pRSV-T) and conjunctival epithelial cell (HC0597) lines were used. Cellular metabolism, cell viability, transwell migration, and the secretion of IL-1 $\beta$, IL-6, and IL-10 were determined. In rabbits, after corneal de-epithelization, eye drops containing $0.002 \%$ and $1 \%$ KYNA were applied five times a day until full recovery. KYNA decreased metabolism but did not affect the proliferation of the corneal epithelium. It decreased both the metabolism and proliferation of conjunctival epithelium. KYNA enhanced the migration of corneal but not conjunctival epithelial cells. KYNA reduced the secretion of IL-1 $\beta$ and IL-6 from the corneal epithelium, leaving IL-10 secretion unaffected. The release of all studied cytokines from the conjunctival epithelium exposed to KYNA was unchanged. KYNA at higher concentration accelerated the healing of the corneal epithelium. These favorable properties of KYNA suggest that KYNA containing topical pharmaceutical products can be used in the treatment of ocular surface diseases.

Keywords: kynurenic acid; corneal epithelium; conjunctival epithelium; accelerated healing

\section{Introduction}

One of the most important challenges in modern ophthalmic pharmacology is how to accelerate the healing of corneal epithelial defects and prevent the migration of conjunctival epithelium onto the cornea. In addition, the reduction of pain and prevention of scarring of the conjunctiva after surgery (especially anti-glaucoma surgery) or trauma will be welcomed. So far, many attempts have been considered in topical therapy of ocular surface including blood derivatives [1], saliva [2], conditioned media from human amniotic epithelial cells [3], the growth hormone [4], and erythropoietin [5], albeit without satisfactory outcomes. 
In the search for an adequate candidate, we focused on endogenous compounds present in tears. In our previous studies, tryptophan (TRP) and its immediate metabolite kynurenine were investigated [6,7]. Kynurenic acid (KYNA) is another TRP metabolite formed along the kynurenine pathway. KYNA is an organic, water-soluble compound that was discovered in dog urine in 1853 by Justus von Liebig [8]. $\mathrm{KYNA}\left(\mathrm{C}_{10} \mathrm{H}_{7} \mathrm{NO}_{3}\right.$; 4-hydroxyquinoline-2-carboxylic acid) has a molecular weight of 189.17 and solubility $>28.4 \mathrm{ug} / \mathrm{mL}$ (https:/ / pubchem.ncbi.nlm.nih.gov, accessed on 22 July 2021). Its chemical structure is shown in Scheme 1.<smiles>O=C(O)c1cc(O)c2ccccc2n1</smiles>

Scheme 1. Chemical structure of kynurenic acid.

KYNA is widely distributed in nature. It is present in body fluids as blood, cerebrospinal fluid, saliva, and tissues including eye structures in mammals. We found that it occurs naturally in tears at a concentration of $0.02 \mu \mathrm{M}$ [9]. It also occurs in plants, vegetables, and herbs as a component of everyday diet [10]. KYNA is considered as a safe and non-toxic substance that cannot cross the blood-brain barrier.

Endogenous KYNA is a product of normal TRP metabolism. More than $90 \%$ of available TRP is catabolized along the kynurenine pathway (KP) [11]. TRP is converted by the first and rate-limiting enzymes, tryptophan 2,3-dioxygenase constitutively present in liver and cytokine-activated indoleamine-2,3-dioxygenase (IDO) broadly distributed in body tissues to $\mathrm{N}$-formyl kynurenine, which is metabolized to kynurenine (KYN) by kynurenine formamidase. KYN is mainly converted to 3-hydroxykynurenine and further downstream metabolites. KYNA synthesis is catalyzed by kynurenine aminotransferases (KATs) I-IV. Previously, we demonstrated the presence of KAT I, II, and III in the healthy human limbal conjunctiva and the cornea. Our findings support the hypothesis that TRP can be metabolized to KYNA in corneal epithelium, endothelium, and stroma [12]. KYNA displays many biological activities. KYNA exhibits anti-inflammatory, antioxidative, analgesic, and antimicrobial properties [13-16]. It is the only known naturally occurring antagonist of endogenous glutamate receptors in the central nervous system. KYNA in low micromolar concentrations antagonizes the glycine site of the $N$-methyl-D-aspartate (NMDA) receptor complex and acts as a potent neuroprotectant. As a result of this activity, it may influence important neurophysiologic and neuropathologic processes including Alzheimer's disease, Huntington's and Parkinson's diseases, multiple sclerosis, epilepsy, brain ischemia, depression, and schizophrenia. Glutamate in high concentration is known for its neurotoxicity in the brain and retina $[17,18]$. In a similar manner, it may play a role in neurotrophic diseases of cornea and the remaining ocular surface structures. In the cornea, glutamate interacts also with its receptors to cause nociception. This suggests that the blockade of these receptors may help in controlling inflammatory or maladaptive pain from the cornea [19].

Furthermore, it has been shown that KYNA is an endogenous antagonist of the alpha7 nicotinic acetylcholine receptor, $G$ protein-coupled receptor 35 (GPR35), and aryl hydrocarbon receptor (AhR) ligand [20,21]. The presence of GPR35 in human corneas has been revealed recently; however, its role in the eye requires further investigation [22]. Accumulated data suggest that GPR35 may play an important role in response to hypoxic stress and be a potential target for the treatment of inflammatory, allergic, and neurological disorders [23]. The potential role of AhR in ocular and non-ocular neurodegenerative 
diseases has been recently reviewed [24]. The beneficial effects of KYNA in a number of pathological conditions have been reported, but no studies have been conducted on its use in the treatment of eye diseases so far.

Since the effect of KYNA on structures of the ocular surface has never been explored in the present study, the influence of KYNA on corneal and conjunctival cells in vitro and the re-epithelization of corneal erosion in rabbits in vivo was investigated.

\section{Results}

\subsection{Effect of KYNA on Metabolic Activity of Corneal and Conjunctival Cells In Vitro}

The incubation of both corneal epithelial cells and conjunctival epithelial cells in medium containing KYNA at concentrations of $1-100 \mu \mathrm{M}$ for $24 \mathrm{~h}$ and $48 \mathrm{~h}$ resulted in a concentration-dependent reduction of metabolic activity of these cells measured with a 3-[4,5-dimethylthiazol-2-yl]-2,5 diphenyl tetrazolium bromide (MTT) assay (Figure 1a,b).

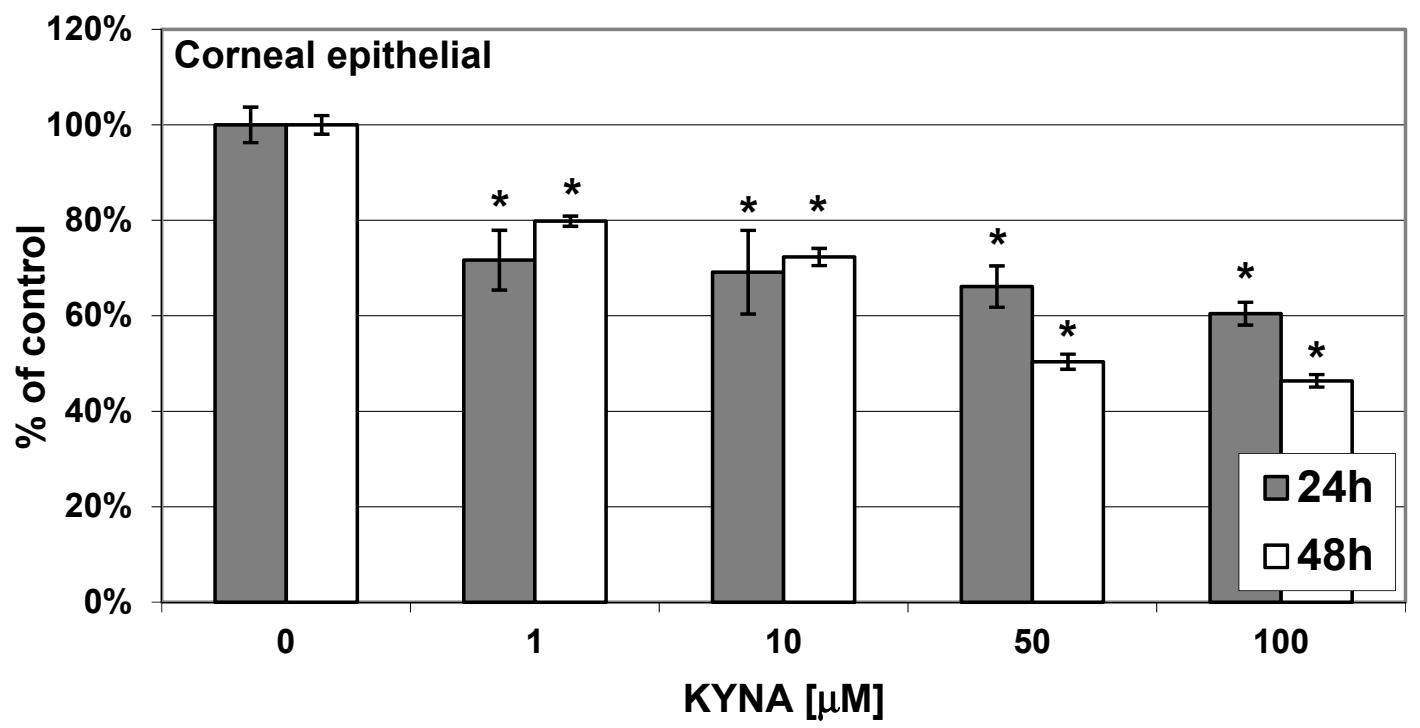

(a)

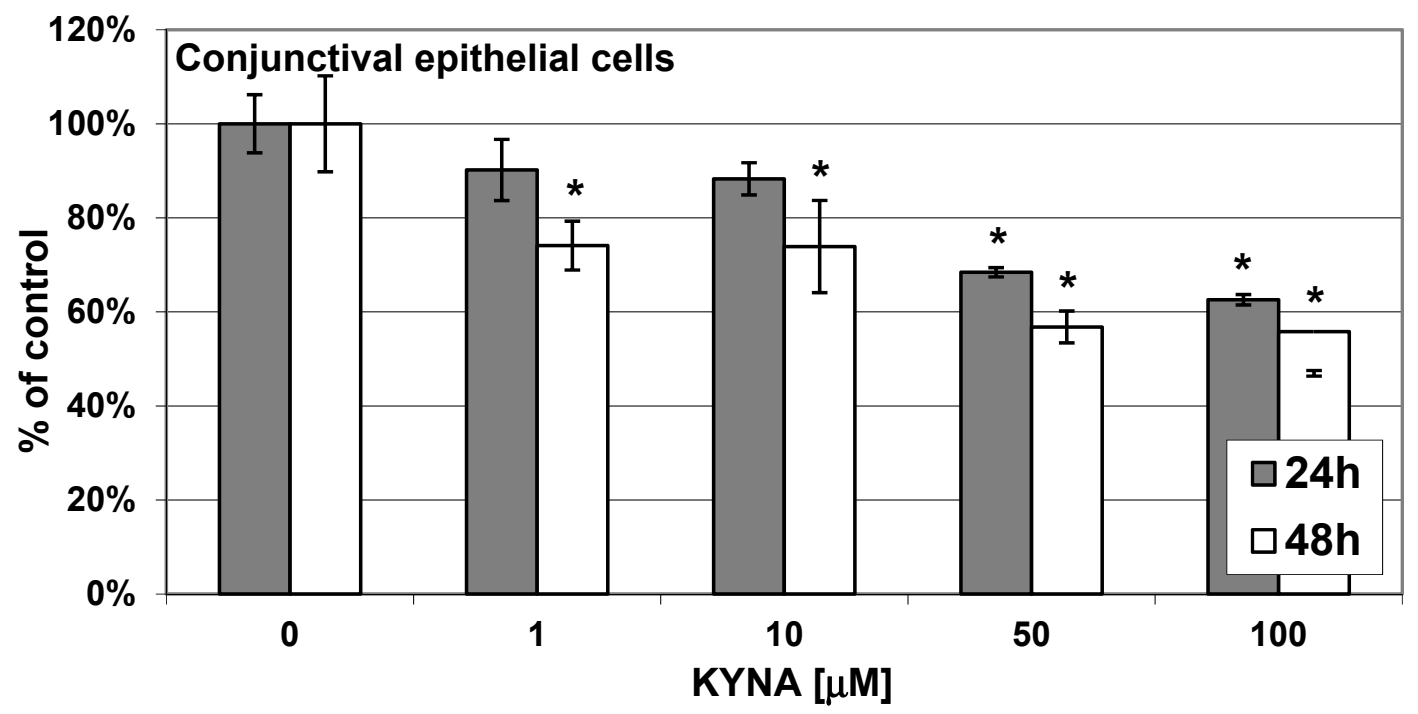

(b)

Figure 1. Effect of KYNA on metabolic activity of (a) human corneal cells (pRSV-T) and (b) human conjunctival cells (HC0597). Cells were incubated with KYNA for $24 \mathrm{~h}$ and $48 \mathrm{~h}$. Metabolic activity was measured by means of 3-[4,5dimethylthiazol-2-yl]-2,5 diphenyl tetrazolium bromide (MTT) assay. ${ }^{*} p<0.05$ vs. respective control. 


\subsection{Effect of KYNA on Viability of Corneal and Conjunctival Cells In Vitro}

The presence of KYNA $(1-100 \mu \mathrm{M})$ in the medium did not affect the viability of corneal epithelial cells measured after incubation lasting for $24 \mathrm{~h}$ and $48 \mathrm{~h}$ using a neutral red (NR) assay (Figure 2a). KYNA (1-100 $\mu \mathrm{M})$ present in the incubation medium transiently reduced the viability of conjunctival epithelial cells. The viability decline was significant after $24 \mathrm{~h}$ but not after $48 \mathrm{~h}$ of incubation. The effect was not concentration-dependent.

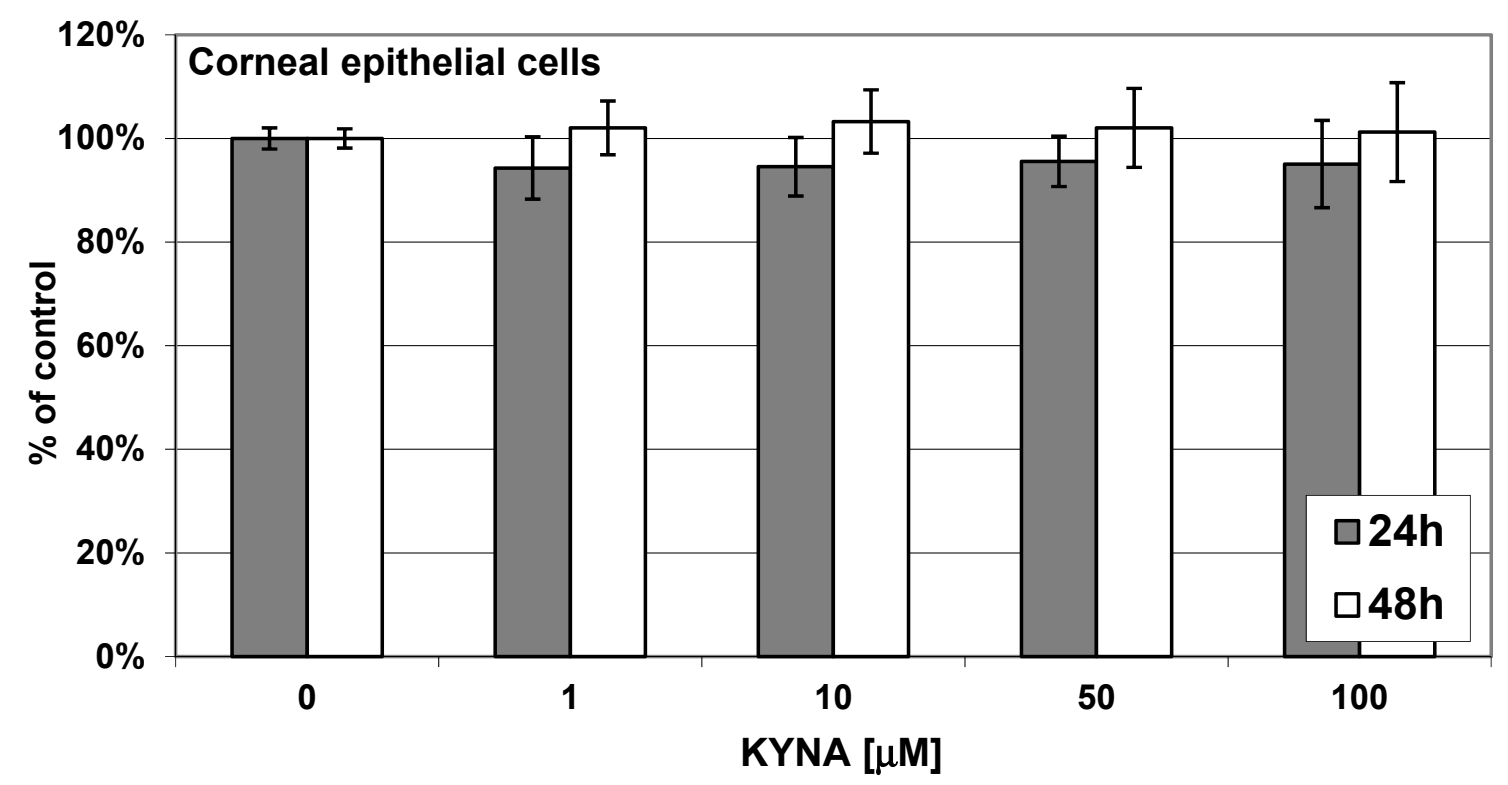

(a)

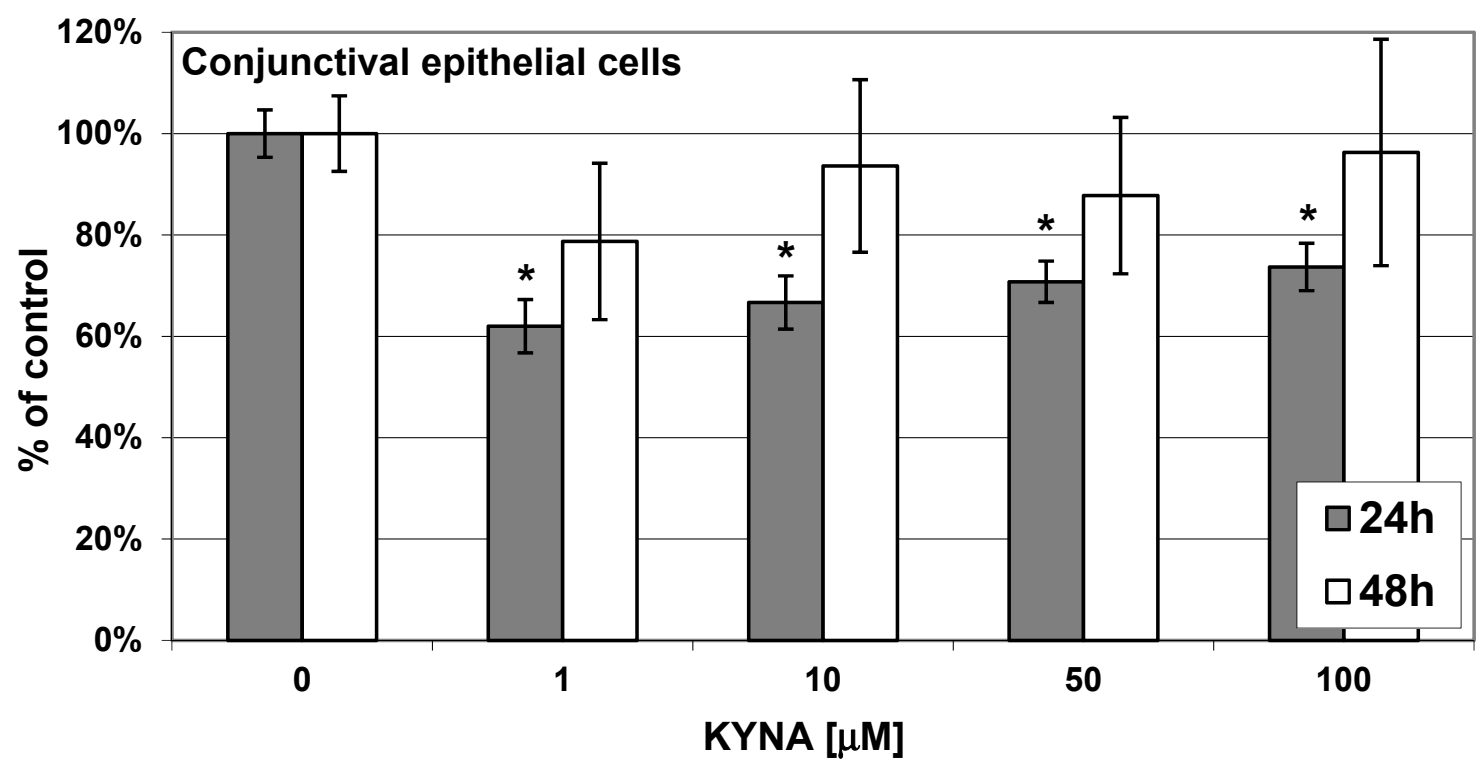

(b)

Figure 2. Effect of KYNA on viability of (a) human corneal cells (pRSV-T) and (b) human conjunctival cells (HC0597). Cells were incubated with KYNA for $24 \mathrm{~h}$ and $48 \mathrm{~h}$. Viability was measured by means of neutral red (NR) assay. ${ }^{*} p<0.05 \mathrm{vs.}$ respective control. 


\subsection{Effect of KYNA on Cellular Cytoskeleton F-Actin Organization of Corneal and Conjunctival Cells}

The following parameters were visually assessed: cell morphology, based on the shape, structure, form, and size of cells and the borderline of the cytoplasmic membrane; condition of the cell membrane, based on its form and linearity; intercellular interactions and adhesion of cells to the culture surface.

KYNA $(10 \mu \mathrm{M}, 100 \mu \mathrm{M})$ did not affect cell morphology in the corneal epithelial cells (Figure 3a) and conjunctival epithelial cells (Figure 3b). In the corneal and conjunctival epithelial cells, the F-active filaments of the cytoskeleton were located mainly near the cytoplasmic membrane. In conjunctival epithelial cells, high concentration of the fibers was also observed in the vicinity of the nuclear membrane.

KYNA $(10 \mu \mathrm{M}, 100 \mu \mathrm{M})$ did not affect intercellular adhesions in the corneal epithelial cells (Figure 3a). In conjunctival epithelial cells incubated in the presence of KYNA at both concentrations, a looser arrangement of cells may indicate a weakening of intercellular connections and, indirectly, a change in the structure of F-actin fibers after the exposure of cells to KYNA (Figure $3 b$ ).
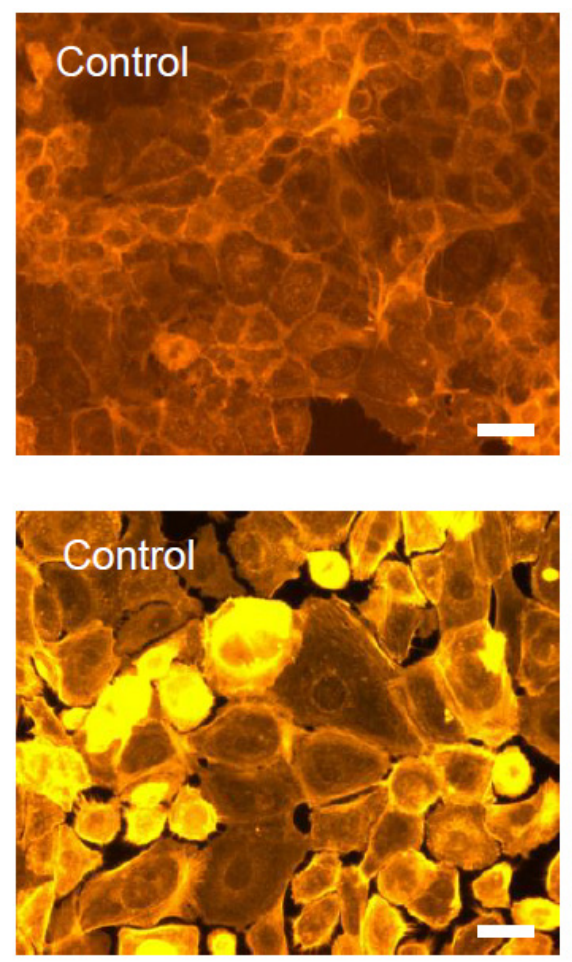

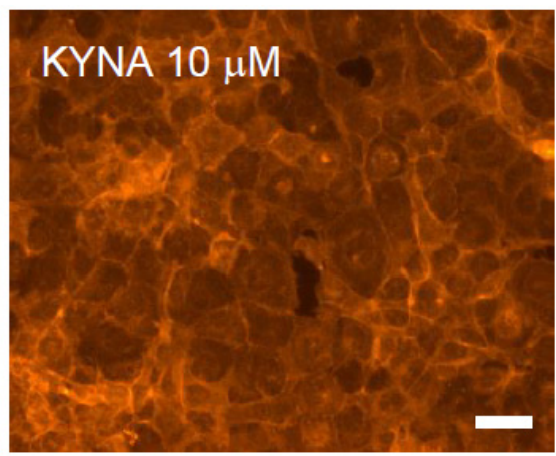

(a)

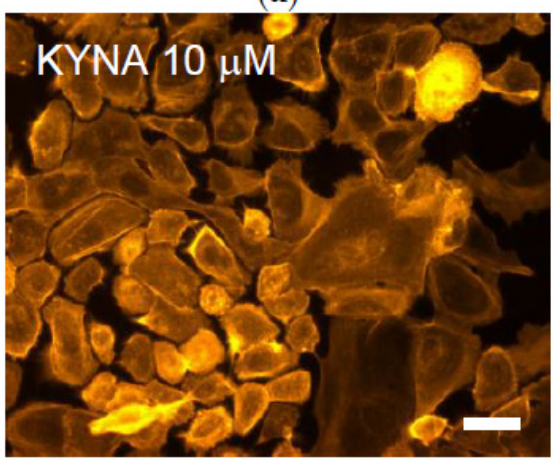

(b)
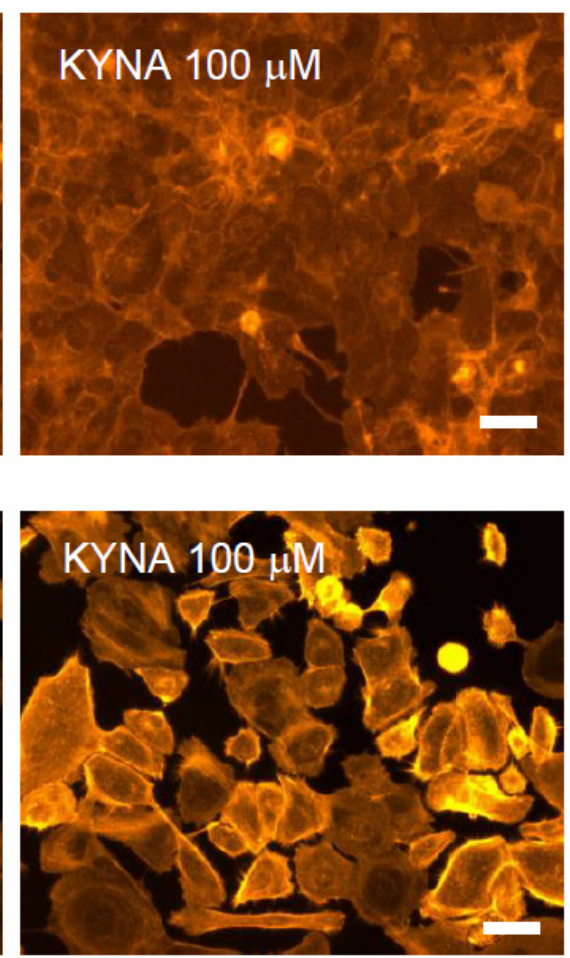

Figure 3. Effect of KYNA on cytoskeleton organization of (a) human corneal cells (pRSV-T) and (b) human conjunctival cells (HC0597). Cells were incubated with KYNA $10 \mu \mathrm{M}$ and $100 \mu \mathrm{M}$ for $24 \mathrm{~h}$ and stained with rhodamine-phalloidin dye. Magnification 100x; bar $=20 \mu \mathrm{m}$. The analyses were performed in 10 microscopes' fields of view for each group. The most representative images are shown.

\subsection{Effect of KYNA on Transwell Migration Capacity of Corneal and Conjunctival Cells In Vitro}

In the presence of KYNA at a concentration of $75 \mu \mathrm{M}$ for $48 \mathrm{~h}$, the migration capacity of corneal epithelial cells was elevated to $208 \%(p<0.05)$, whereas that of conjunctival epithelial cells was not significantly enhanced up to $120 \%(p>0.05)$ as compared to control (set as 100\%) (Table 1). 
Table 1. Effect of KYNA on transwell migration capacity of human cornea cells (pRSV-T) and human conjunctiva cells (HC0597) in vitro.

\begin{tabular}{ccccc}
\hline & \multicolumn{2}{c}{ pRSV-T } & \multicolumn{2}{c}{ HC0597 } \\
& $\begin{array}{c}\text { Number of Cell } \\
\text { Counts }\end{array}$ & \% of Control & $\begin{array}{c}\text { Number of Cell } \\
\text { Counts }\end{array}$ & \% of Control \\
\hline Control & $13 \pm 2.6$ & 100 & $10 \pm 1.5$ & 100 \\
KYNA & $27 \pm 7.0^{*}$ & $208^{*}$ & $12 \pm 4.0$ & 120 \\
\hline
\end{tabular}

Transwell migration assay, pore size $0.4 \mu \mathrm{m}$. Cells were incubated with KYNA $75 \mu \mathrm{M}$ for $48 \mathrm{~h}$. Giemsa staining. In order to quantify the migration capacity of cells, the stained parts of cells were counted under a microscope at $40 \times$ magnification. Data are presented as a mean $\pm S D ; * p<0.05$ vs. respective control.

\subsection{Effect of KYNA on Cytokine Release by Corneal and Conjunctival Cells In Vitro}

Obtained results demonstrated that KYNA stimulates corneal and conjunctival epithelial cells to secret cytokines, thus pointing to its mediatory role in immune response.

The incubation of corneal epithelial cells in a medium containing KYNA at concentrations of $1 \mu \mathrm{M}$ and $10 \mu \mathrm{M}$ for $24 \mathrm{~h}$ and $48 \mathrm{~h}$ did not significantly affect the release of IL-1 $\beta$ except for the decreased release of this cytokine after $24 \mathrm{~h}$ of cell incubation with KYNA $10 \mu \mathrm{M}$ (Figure 4a).

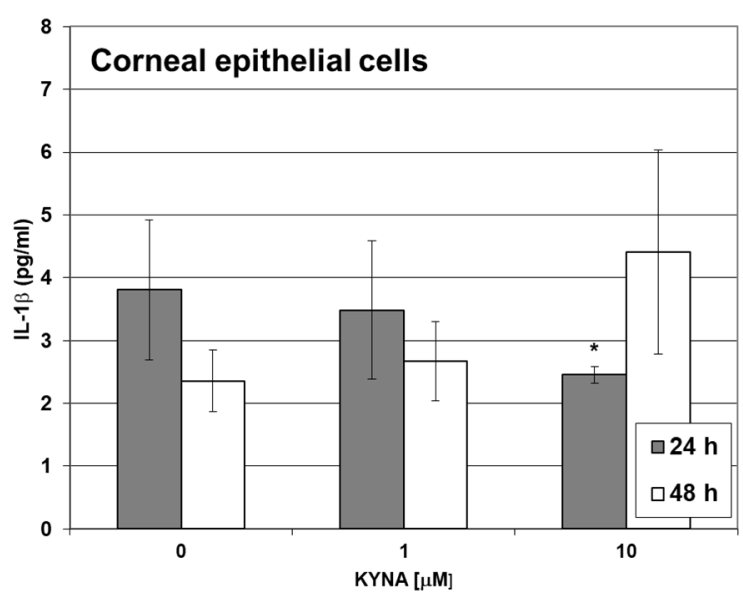

(a)

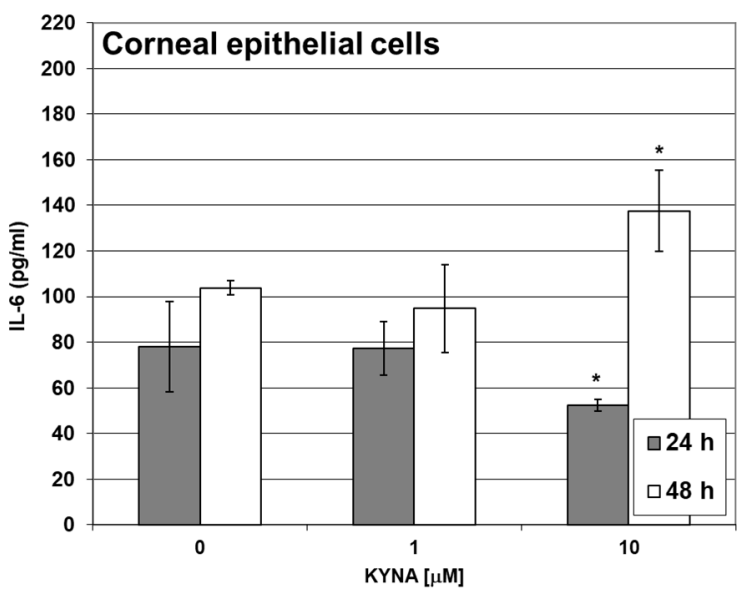

(c)

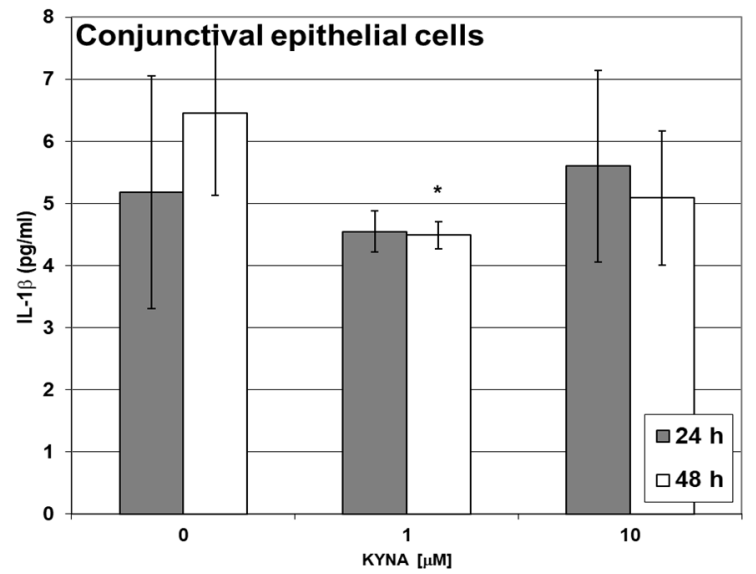

(b)

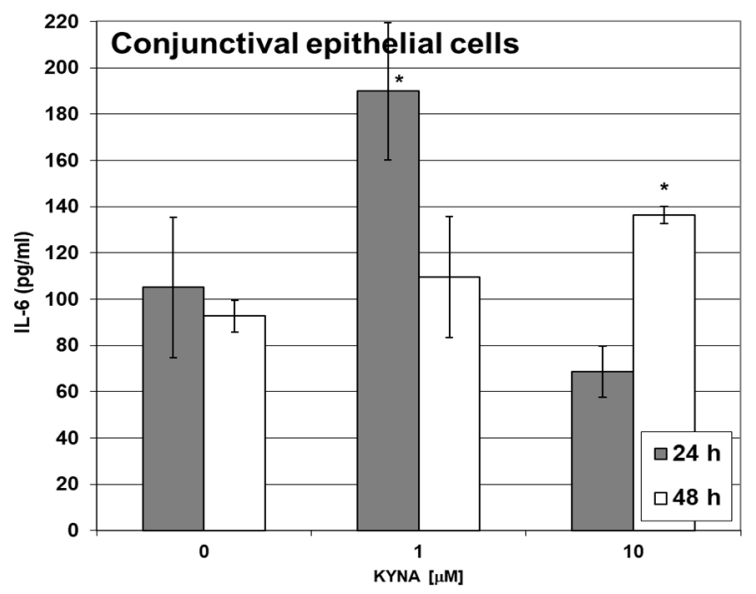

(d)

Figure 4. Cont. 


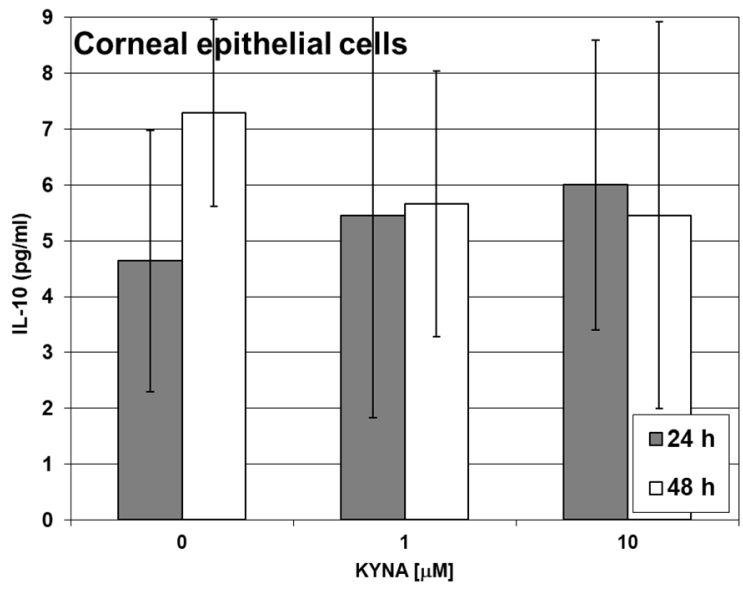

(e)

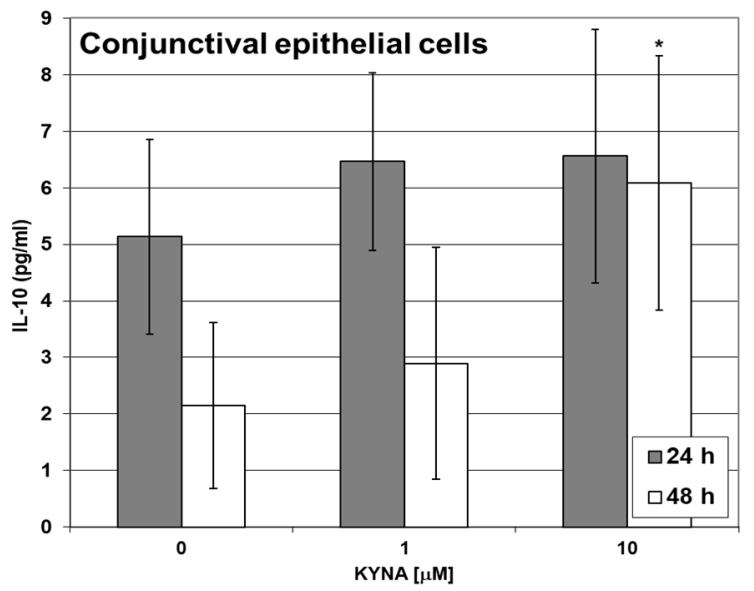

(f)

Figure 4. Effect of KYNA on the release of cytokines from (a,c,e) human corneal cells (pRSV-T) and (b,d,f) human conjunctival cells (HC0597). Cells were incubated with KYNA $1 \mu \mathrm{M}$ and $10 \mu \mathrm{M}$ for $24 \mathrm{~h}$ and $48 \mathrm{~h} .{ }^{*} p<0.05$ vs. respective control.

The incubation of conjunctival epithelial cells in a medium containing KYNA at a concentration of $1 \mu \mathrm{M}$ significantly reduced the release of IL-1 $\beta$ after $24 \mathrm{~h}$ and $48 \mathrm{~h}$ incubation. KYNA at a higher concentration $(10 \mu \mathrm{M})$ was ineffective in this regard (Figure $4 \mathrm{~b})$.

The release of IL- 6 was reduced and enhanced by KYNA $10 \mu \mathrm{M}$ from corneal epithelial cells incubated for $24 \mathrm{~h}$ and $48 \mathrm{~h}$, respectively (Figure 4c). The release of IL-6 was enhanced by KYNA $1 \mu \mathrm{M}$ and $10 \mu \mathrm{M}$ from conjunctival epithelial cells incubated for $24 \mathrm{~h}$ and $48 \mathrm{~h}$, respectively (Figure $4 \mathrm{~d}$ ).

The release of IL-10 from corneal epithelial cells was unaffected by the presence of KYNA in the medium at both concentrations studied: $1 \mu \mathrm{M}$ and $10 \mu \mathrm{M}$, which were measured after $24 \mathrm{~h}$ and $48 \mathrm{~h}$ of incubation (Figure $4 \mathrm{e}$ ). The release of IL-10 from conjunctival epithelial cells was unaffected by the presence of KYNA in the medium at both concentrations studied: $1 \mu \mathrm{M}$ and $10 \mu \mathrm{M}$, which were measured after $24 \mathrm{~h}$ and $48 \mathrm{~h}$ of incubation except for increased release of this cytokine after $48 \mathrm{~h}$ of cell incubation with KYNA $10 \mu \mathrm{M}$ (Figure 4f).

\subsection{Effect of KYNA on Corneal Epithelialization In Vivo}

Eye drops containing KYNA were administered five times daily for 3 days. The administration of eye drops containing KYNA at a concentration of $0.002 \%$, which corresponds to the highest concentration used in in vitro experiments $(100 \mu \mathrm{M})$, did not affect the duration of healing of experimentally induced erosion of the cornea in rabbits (data not shown). The administration of eye drops containing KYNA at a concentration of $1 \%$ significantly shortened the duration of healing of experimentally induced erosion of the cornea in rabbits (Figure 5a; Table 2). The dynamics of the re-epithelization process was unaffected by KYNA up to $24 \mathrm{~h}$ after insult and significantly accelerated thereafter as compared to control (Figure 5b). Careful examinations performed throughout the entire study by two experts, an authorized veterinarian and an experienced human ophthalmologist, did not reveal any adverse effects of tested drops. No signs of discomfort of animals were found. The condition of cornea and conjunctiva was evaluated using a biomicroscope (a slit lamp examination without and with cobalt blue filter after fluorescein administration). The appearance of these structures was documented photographically at the time of wound area measurement, i.e., every $12 \mathrm{~h}$ for 3 days for the whole period of applications of eye drops. 


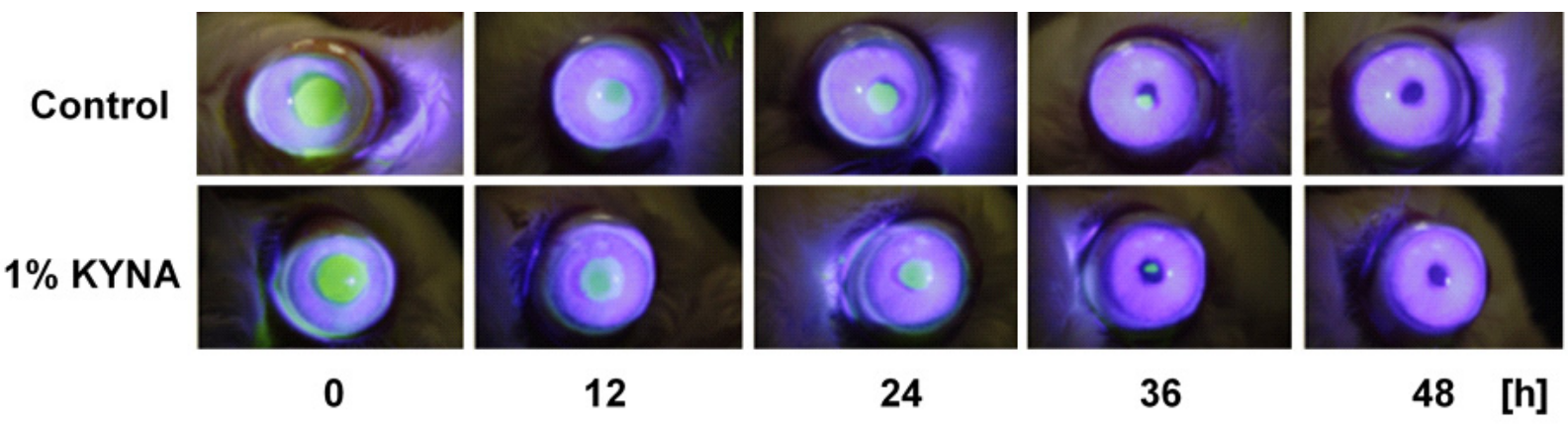

(a)

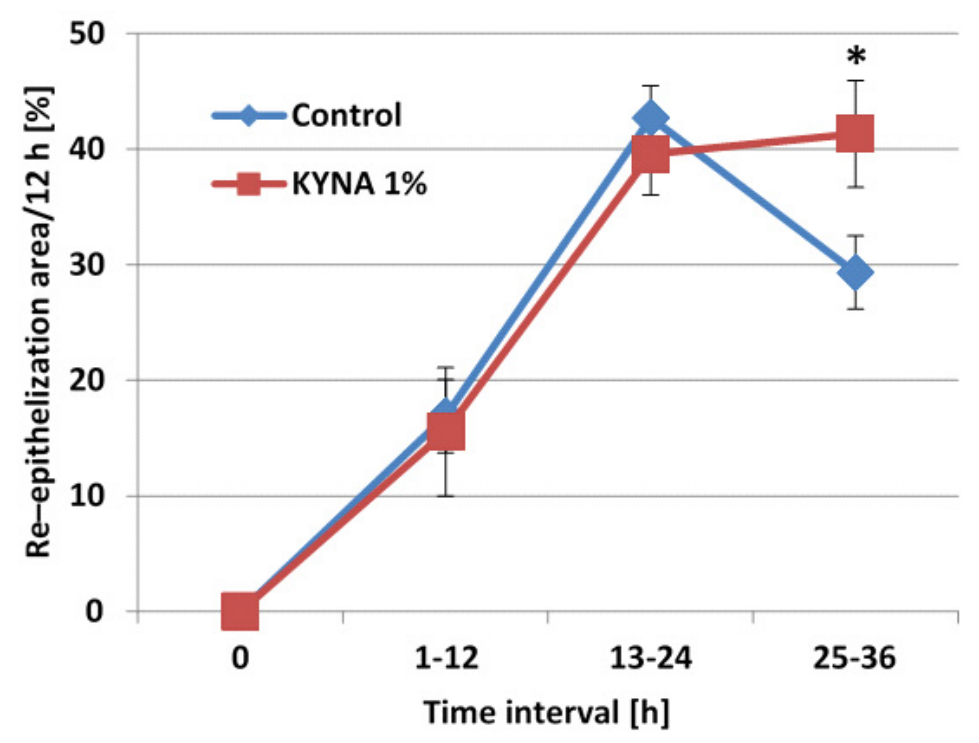

(b)

Figure 5. Effect of eye drops containing KYNA on re-epithelization of experimentally induced corneal erosion in rabbit. (a) A representative pattern recorded in $12 \mathrm{~h}$ intervals after insult. Upper row: $0.9 \%$ saline-treated eye (control); lower row: 1\% KYNA-treated eye. Areas devoid of corneal epithelium are marked green with fluorescein. (b) Wound-healing rate calculated as a difference between erosion areas measured in $12 \mathrm{~h}$ intervals (re-epithelization area/12 h); data are presented as a percentage of the initial insult area. Data are presented as a mean $\pm \mathrm{SD} ;{ }^{*} p<0.05$ vs. respective control value.

Table 2. Effect of eye drops containing 1\% KYNA on re-epithelization of experimentally induced corneal erosion in rabbits-a cohort analysis.

\begin{tabular}{ccc}
\hline \multirow{2}{*}{ Time $[\mathrm{h}]$} & \multicolumn{2}{c}{ Erosion Area [\%] } \\
\cline { 2 - 3 } & Control & KYNA 1\% \\
\hline 0 & $100 \pm 3.6$ & $100 \pm 3.2$ \\
12 & $83 \pm 3.4$ & $84 \pm 3.8$ \\
36 & $40 \pm 2.5$ & $45 \pm 2.1$ \\
48 & $12 \pm 4.5$ & $4 \pm 1.4$ \\
* & 0 \\
\hline
\end{tabular}

Data are presented as a mean $\pm \mathrm{SEM} ;^{*} p<0.05$ vs. respective control value, Wilcoxon matched-pairs signed-ranks test. 


\section{Discussion}

In this study, for the first time, we showed that KYNA accelerates the re-epithelization of experimentally induced corneal erosion in rabbits in vivo. The administration of KYNA containing eye drops accelerated the process of re-epithelization $36 \mathrm{~h}$ after surgery, leading to an earlier full recovery of the corneal surface. This observation is consistent with the results of in vitro experiments in which KYNA promoted the migration of human corneal epithelium. This conclusion is consistent with the finding of Poormasjedi-Meibod et al. (2014) that KYNA accelerated keratinocyte migration, as measured in scratch assay in vitro [25]. The molecular mechanisms responsible for the healing properties of KYNA is unclear. KYNA is a NMDA receptor antagonist. However, according to Oswald et al. (2012), activation rather than inhibition of the NR1 subunit of the NMDA receptor in concert with purinergic mechanisms stimulates the healing processes in a co-culture of human corneal limbal epithelial cells, and primary trigeminal neurons and NMDA antagonists expressed opposite effects [26]. Interestingly, KYNA is also an agonist of the AhR and GPR35 receptors [27]. Although the presence of AhR in cornea was established, it is unclear whether this receptor participates in repair processes [28]. Ikuta et al. 2008 did not find any significant difference in skin wound closure between wild-type and AhRR-/- mice. On the contrary, they found that the inactivation of AhR accelerates wound healing in the early inflammatory phase of this process [29]. This result has to be treated with caution, since a substantial lack of homology between AhR signaling in mice and in humans was reported, which is due to very low sequences homology in the C-terminal transactivation domain of AhR [30,31]. Ultimately, the healing effect of KYNA could be explained by the activation of GPR35 in the corneal epithelium. Recently, the presence and distribution of GPR35 receptors in the human cornea was demonstrated [22]. Furthermore, Tsukahara et al. (2017) reported that GPR35 agonists promoted wound repair of mouse colon epithelium [32]. The indirect effect of KYNA should be also considered. It has been shown that the process of corneal healing is complex, and many neuropeptides/neurotransmitters and receptors are involved in cell proliferation and migration [33]. Thus, the anti-inflammatory and immunosuppressive functions of KYNA may play a role in regulating healing processes as well [34].

Although KYNA reduced cell metabolism, it did not affect the viability of corneal epithelium in vitro. Additionally, it did not influence the cytoskeleton and cell-cell junctions in the corneal epithelial cells. Accordingly, the lack of toxic effects of KYNA applied in a wide range of concentrations was confirmed in our previous study, in which an HCE three-dimensional model consisting of immortalized human corneal epithelial cells was utilized, pointing to the safety of KYNA application on the eye surface [6].

Another aspect of healing corneal epithelial wounds in vivo is the unwanted migration of conjunctival epithelial cells across the denuded limbus to cover the corneal: the process termed conjunctivalization [35]. It was reported that the area of cornea covered by the conjunctival epithelium appeared dysfunctional, thin, and irregular; it attracted new vessels and was prone to recurrent erosions. Moreover, conjunctivalization of the visual axis affected vision; therefore, the mechanical removal of the conjunctival epithelium from the cornea is recommended [35]. Intriguingly, we found that KYNA impairs both the metabolism and viability of the conjunctival epithelium and influences intercellular adhesions among cells in vitro. In contrast to its effect exerted on the corneal epithelium, KYNA does not enhance the migratory capacity of the cells in conjunctival epithelium. Such properties (see Table 3) imply that KYNA could reduce the severity or prevent the conjunctivalization of cornea. This assumption needs confirmation in an appropriate animal model and/or clinical trial. 
Table 3. Effects exerted by KYNA on corneal and conjunctival epithelial cells in vitro-a comparison.

\begin{tabular}{ccc}
\hline Effect & Corneal Epithelial Cells & Conjunctival Epithelial Cells \\
\hline Metabolism reduction & YES & YES \\
Viability reduction & NO & YES \\
Cytoskeleton impairment & NO & YES \\
Migratory activity & YES \\
enhancement & NO
\end{tabular}

Based on own presented results.

In recent years, numerous in vivo and in vitro studies have been directed toward the immunomodulatory functions of KYNA. Therefore, we studied the release of cytokines IL-1 $\beta$, IL-6, and IL-10 from corneal and conjunctival cells in culture exposed to KYNA. We found that KYNA-induced changes in cytokine production varied markedly by the cell type, drug concentration, and incubation time. We found that KYNA enhanced the release of IL-1 $\beta$ from corneal and conjunctival cells, and this result agreed with data, presenting an increased release of cytokines from the corneal epithelium during injuries [36]. KYNA enhanced the release of IL- 6 from corneal and conjunctival cells. This pro-inflammatory cytokine is thought to play an important role in corneal epithelial wound closure in vivo and to stimulate the migration of human corneal epithelial cells in vitro [37-39]. We also found that in a conjunctival epithelium culture, KYNA enhanced the release of IL-10; the cytokine is known to promote anti-inflammatory and anti-angiogenic processes in the cornea and conjunctiva [40] as well as inducing corneal transplantation immune tolerance [41]. Our results suggest that the KYNA-induced release of cytokines may affect the wound healing of the cornea, since it was shown by Arranz-Valsero et al. (2014) that the presence of IL-6 or IL-10 increased the wound-healing rate in an in vitro corneal wound-healing model [38].

Furthermore, KYNA possesses other favorable properties of potential beneficial applications in ophthalmology. Csati et al. (2015) [42] have shown that KYNA reduced experimentally induced inflammation in the mandibular part of the trigeminal ganglion. Since the administration of KYNA resulted in the inhibition of the signaling system of the trigeminal ganglion, it could be speculated that KYNA may reduce corneal pain without nerve damage. This assumption is strengthened by the evidence on the antimigraine and pain-relieving activity of KYNA and its analogues $[43,44]$ The antinociceptive properties of KYNA topically administered to the conjunctival sac have yet to be established.

The antiscarring properties of topically applied KYNA in a skin wound-healing model in rabbits and rats were reported [25,45]. Importantly, KYNA enhanced the expression of matrix metalloproteinases MMP1 and MMP3 and suppressed the production of type I collagen and fibronectin by fibroblasts [25]. Based on these results, it could be assumed that topically administered KYNA may reduce conjunctival and scleral scarring after glaucoma surgery, which is a major limiting factor to the success of this procedure [46]. Moreover, the use of KYNA to inhibit the overgrowth of stromal fibroblasts and aberrant matrix remodeling in pterygium also could be postulated. It was revealed that KYNA protected endothelial cells in culture against homocysteine-induced cytotoxicity [47]. Increased homocysteine levels in tears and plasma were found in patients with glaucoma [48]. A link between high homocysteine and other eye diseases such as retinopathy, maculopathy, cataract, optic atrophy, and retinal vessel atherosclerosis is suggested [49].

KYNA is an endogenous substance and diet constituent but it is not approved as a drug. It is important to note in this regard that the results of a phase 1 clinical trial of topically administered KYNA were published recently [50]. KYNA was applied to the skin of volunteers at concentrations ranging from $0.15 \%$ to $0.5 \%$. The skin reaction was estimated $24 \mathrm{~h}$ later. The procedure was repeated after 14 days to establish a potential delayed allergic reaction. No adverse reactions were recorded. Moreover, no sign of absorption of KYNA from the skin was recorded in blood and urine [50].

Interestingly, KYNA was identified as UV filter [51]. Thus, its presence in a lens might have an additional beneficial effect; i.e., protection of the lens and retina from photodamage. 
On the other hand, it was found that KYNA is the most photochemically active dye of the human eye lens reported to date [52]. In the lens, under physiological conditions, KYNA is formed from kynurenines undergoing thermal and photochemical reactions [53]. It was suggested that due to the high yield of the triplet state of its active form, it may contribute to the photodamage of lens proteins [52]. Thus, its involvement in cataract development cannot be excluded. In fact, elevated content of KYNA was detected in cataractous lenses [54]. The question remains open of whether KYNA applied topically may enhance the content of KYNA in its active states in lenses? The penetration of KYNA through the cornea after topical administration is unknown, as well as its concentration in the aqueous humor of the anterior chamber in healthy eyes. However, the presence of endogenous KYNA was detected in the aqueous humor of the anterior chamber of cataractous eyes [55].

In conclusion, KYNA showed no toxicity to human conjunctival and corneal epithelium in a wide range of concentrations. Its action profile-accelerated healing of corneal epithelium with simultaneous lack of stimulation of conjunctival epithelial cells-seems to be beneficial from the point of view of treatment of many ocular surface disorders. KYNA is a compound with a multidirectional effect proposed for the treatment of neurological diseases. However, it was hampered by the fact that KYNA does not cross the blood-brain barrier. It is necessary to undertake further studies on the effect of KYNA on other types of cells present in structures forming the ocular surface. Summing up, all the above-described features make KYNA a drug candidate with wide therapeutic potential in the therapy of ophthalmic diseases.

\section{Materials and Methods}

\subsection{Materials}

KYNA was purchased from Sigma-Aldrich (St. Louis, MO, USA). The purity of the KYNA was $\geq 98 \%$. Substance was used without further purification.

\subsection{In Vitro Studies \\ 4.2.1. Cell Cultures}

A human normal corneal epithelial cell line 10.014 pRSV-T (ATCC No. CRL-11515) and human normal epithelial conjunctival cell line (ATCC No. CRL-12658) were used. Cells were cultured as monolayers in $25 \mathrm{~cm}^{2}$ culture flasks (Nunc. Roskilde, Denmark) coated with PureCol $^{\mathrm{TM}}$ ultrapure collagen (INAMED Biomaterials, Fremont, CA, USA) at $3.1 \mathrm{mg} / \mathrm{mL}$ concentration. One $\mathrm{mL}$ of collagen was poured into the bottles or plate wells, spread over the entire surface, and after $3 \mathrm{~min}$, the excess solution was removed. The remaining collagen was dried in a thermostat at $37^{\circ} \mathrm{C}$. The cell line was maintained in defined K-SFM (keratinocyteserum free medium) (Gibco ${ }^{\mathrm{TM}}$, Paisley, UK) supplemented with the $75 \mu \mathrm{g} / \mathrm{mL}$ endothelial cell growth factor (ECGF) (Sigma, St. Louis, MO, USA), $0.05 \mathrm{mg} / \mathrm{mL}$ bovine pituitary extract (BPE) (Gibco), $500 \mathrm{ng} / \mathrm{mL}$ hydrocortisone (Sigma), and $0.0005 \mathrm{mg} / \mathrm{mL}$ bovine insulin (Gibco), and antibiotics (100 U/mL penicillin, $100 \mu \mathrm{g} / \mathrm{mL}$ streptomycin) (Sigma, St Louis, MO) at 37 ${ }^{\circ} \mathrm{C}$ in a humidified atmosphere with $5 \% \mathrm{CO}_{2}$.

\subsubsection{Experimental Schedule}

Human corneal and conjunctival epithelial cell suspension $\left(1 \times 10^{5}\right.$ cells $\left./ \mathrm{mL}\right)$ in a culture medium was added to the appropriate culture dishes (96-well or 24-well) and incubated for $24 \mathrm{~h}$ at $37^{\circ} \mathrm{C}$ in a humidified $5 \% \mathrm{CO}_{2} / 95 \%$ air incubator. Thereafter, the medium was replaced with a new one containing appropriate concentrations of KYNA $(0-100 \mu \mathrm{M})$. A blank control consisted only of culture medium. Incubation of cells $\left(1 \times 10^{5}\right.$ cells $\left./ \mathrm{mL}\right)$ with KYNA was continued for $24 \mathrm{~h}$ and $48 \mathrm{~h}$.

\subsubsection{Cell Metabolism and Viability-MTT Assay}

The 3-[4,5-dimethylthiazol-2-yl]-2,5 diphenyl tetrazolium bromide (MTT) assay is based on the conversion of a yellow tetrazolium salt by viable cells to purple crystals of 
formazan. The reaction is catalyzed by mitochondrial succinate dehydrogenase. Cells grown in 96-well multiplates in $100 \mu \mathrm{L}$ of culture medium for $24 \mathrm{~h}$ or $48 \mathrm{~h}$ of incubation with KYNA were further incubated for $3 \mathrm{~h}$ with MTT solution $(5 \mathrm{mg} / \mathrm{mL}, 25 \mu \mathrm{L} /$ well $)$ (Sigma-Aldrich). The crystals of formazan were solubilized overnight in a 10\% sodium dodecyl sulfate (SDS) in $0.01 \mathrm{M} \mathrm{HCl}$. The product was quantified spectrophotometrically by absorbance measurements at $570 \mathrm{~nm}$ using an E-max Microplate Reader (Molecular Devices Corporation; Menlo Park, CA, USA).

\subsubsection{Cell Viability-Neutral Red (NR) Uptake Assay}

The NR cytotoxicity assay is based on the uptake and lysosomal accumulation of the neutral red dye. Dead or damaged cells do not take up the dye. Cells were grown in 96-well multiplates in $100 \mu \mathrm{L}$ of culture medium (K-SFM) with KYNA. Subsequently, the medium was discarded, and $0.4 \%$ NR (Sigma) solution was added to each well. The plate was incubated for a further $3 \mathrm{~h}$ at $37^{\circ} \mathrm{C}$ in a humidified $5 \% \mathrm{CO}_{2} / 95 \%$ air incubator. After incubation, the dye-containing medium was removed, cells were fixed with $1 \% \mathrm{CaCl}_{2}$ in $4 \%$ paraformaldehyde, and the incorporated dye was solubilized using $1 \%$ acetic acetate in a 50\% ethanol solution $(100 \mu \mathrm{L})$. The plates were gently shaken for $20 \mathrm{~min}$ at room temperature, and the extracted dye absorbance was measured spectrophotometrically at $540 \mathrm{~nm}$.

\subsubsection{Cellular Cytoskeleton F-Actin Organization Analysis}

Cells were incubated in 4-well Lab-Tek chamber slides (Nunc) filled with $1 \mathrm{~mL}$ of culture medium supplemented with KYNA at a 10 or $100 \mu \mathrm{M}$ concentration. After incubation, the cells were rinsed with K-SFM medium and exposed to paraformaldehyde $(10 \%$, $v / v)$ solution for $20 \mathrm{~min}$., rinsed three times in PBS, exposed to Triton X-100 $(0.2 \%, v / v)$ (Sigma) solution for $5 \mathrm{~min}$, and rinsed three times with PBS. Then, $0.5 \mathrm{~mL}$ PBS containing tetramethyl-rhodamine-isothiocyanatephalloidin (TRITC-phalloidin, $1 \mu \mathrm{g} / \mathrm{mL}$ ) (Sigma) was added to each well and incubated in the dark at $37{ }^{\circ} \mathrm{C} / 5 \% \mathrm{CO}_{2}$ for $30 \mathrm{~min}$. Cell analysis was conducted under a fluorescent microscope (Olympus, BX51, Tokyo, Japan). A qualitative assessment of fluorescent images was performed using the AnalySIS imaging software system.

\subsubsection{Transwell Migration Test}

The analysis was performed in 24-well plates with inserts ( $0.4 \mu \mathrm{m}$ pore membrane) (Nunc). Corneal and conjunctival epithelial cells $\left(1 \times 10^{5}\right.$ cells $\left./ \mathrm{mL}\right)$ were seeded into the upper chambers. Culture medium was placed into the upper chamber $(150 \mu \mathrm{L})$, while the medium in the lower chamber $(600 \mu \mathrm{L})$ contained KYNA at $75 \mu \mathrm{M}$ concentration. The experiment was conducted for $48 \mathrm{~h}$ at $37^{\circ} \mathrm{C}$ in a humidified atmosphere with $5 \% \mathrm{CO}_{2}$. Cytoplasmic projections through the membrane's pores were fixed with $4 \%$ paraformaldehyde for $10 \mathrm{~min}$ and stained with a Giemsa stain (Sigma) for $20 \mathrm{~min}$. Cells adhered to the upper surface of the membrane were removed using a cotton swab. In order to quantify the number of migrating cells, the stained parts of cells (pseudopodia) were counted under a microscope (Olympus BX51, Tokyo, Japan) at 40× magnification.

\subsubsection{ELISA Assay}

The level of human IL-1 $\beta$, IL-6, and IL-10 was measured by an immunoenzymatic method (ELISA) using a commercially available kit (BD OptEIATM, San Jose, CA, USA) according to the manufacturer's instruction. The optical density set at $450 \mathrm{~nm}$ was determined using a microplate reader (Molecular Devices Corp., Emax, Menlo Park, CA, USA). The concentration of the cytokines was calculated based on the standard curve. The detection limit was $0.8 \mathrm{pg} / \mathrm{mL}$ for IL- $1 \beta, 2.2 \mathrm{pg} / \mathrm{mL}$ for IL-6, and $2 \mathrm{pg} / \mathrm{mL}$ for IL-10. 


\subsection{In Vivo Studies \\ 4.3.1. Animals}

Sixteen healthy New Zealand white rabbits of both sexes weighing between 3.0 and $3.3 \mathrm{~kg}$ were used. The animals were kept in single cages upon arrival in the facilities under standard conditions of temperature $\left(21^{\circ} \mathrm{C}\right)$ and $12: 12 \mathrm{~h}$ light/dark cycle, with food and tap water provided ad libitum. After a week of adaptation in the facility, the animals were admitted to the experimental session. To exclude any disease that could interfere with the re-epithelization process, the eyes of all animals were previously examined with a slit lamp. The rabbits were kept in restraining boxes only during the experiments.

\subsubsection{Anesthesia and Surgical Procedure}

The rabbits were anesthetized with an intramuscular injection of $1.2-1.8 \mathrm{~mL}$ of a ketamine/xylocaine mixture $(7: 1, v: v)$. All of them underwent a bilateral corneal deepithelialization procedure according to Moshirfar et al. [56]. The surgery was performed by an experienced surgeon as follows. After a wire lid speculum was installed, approximately $0.5 \mathrm{~mL}$ of $20 \%$ ethanol was placed on the central cornea within the barrel of a $6 \mathrm{~mm}$ marking trephine. After $60 \mathrm{~s}$, the ethanol was removed with a cellulose sponge, and the surface of the eye was irrigated with $0.9 \%$ saline solution for $60 \mathrm{~s}$. The ethanol-exposed epithelium was removed with a saline-moistened sponge or a spatula when necessary. Then, the same procedure was repeated on the contralateral eye.

\subsubsection{Treatment}

Postoperatively, each rabbit received a solution of KYNA $(0.002 \%$ or $1 \%)$ and $0.9 \%$ saline solution in the form of eye drops in the right and left eye, respectively. The schedule for the designated drop medication was 5 times a day, up to $72 \mathrm{~h}$, or until complete epithelial healing occurred. The first dose was applied immediately after de-epithelialization of the cornea and documentation of the lesion size (time 0 ). To obtain $0.002 \%$ solution, KYNA was dissolved in $0.9 \%$ saline at room temperature. To obtain a $1 \%$ solution of KYNA, it was necessary to dissolve it in $1 \mathrm{~N} \mathrm{NaOH}$ until the substance was completely dissolved. Then, saline was added, and the solution was adjusted with $\mathrm{HCl}$ to $\mathrm{pH}$ approximately 7.5.

\subsubsection{Evaluation of Corneal Epithelialization}

The lesions of both eyes were examined immediately (time 0 ) and every $12 \mathrm{~h}$ postoperatively. This involved the application of fluorescein (BIO-GLO, Hub Pharmaceuticals LCC, Rancho Cucamonga CA, USA) into the eye, without topical anesthesia, followed by a slit lamp examination under cobalt blue light. Digital images were taken with a Canon EOS 450D 12.2 megapixel camera (Canon Inc., Tokyo, Japan), coupled to a YZ5X1 slit lamp (66 Vision-Tech Co., Ltd., Suzhou, China).

\subsubsection{Image Analysis System}

The digital images were evaluated using the EPCO 2000 (Prof. Dr M. Tetz, Augentagesklinik Spreebogen, Germany) computer analysis system, which offers greater precision than slit lamp measurements. The EPCO 2000 computerized system (developed by Tetz et al. [57]) was originally created for the evaluation of posterior capsule opacification. However, it has already been used for the analysis of corneal epithelial defect surface areas in rabbits as well [56]. The area of the corneal epithelial defect was outlined with a hand-held pointing device and measured in pixels. The re-epithelization rate was assessed as a ratio of the actual epithelial defect area to its initial size at time zero (percentage of the control value).

\subsection{Statistical Analysis}

Results of in vitro experiments $(\mathrm{n}=3)$ and in vivo experiments $(\mathrm{n}=8)$ are presented as a mean \pm standard deviation (SD) or standard error of the mean (SEM). Statistical analysis 
was performed using one-way analysis of variance ANOVA followed by Dunnett's multiple comparison post hoc test. Differences of $p<0.05$ were considered significant.

Author Contributions: A.M.-W., W.A.T., R.P. and R.R.; methodology, A.M.-W., R.P., R.R. and W.A.T.; software, R.P., W.A.T. and M.T.; validation, A.M.-W., R.P., W.A.T. and M.T.; formal analysis, A.M.-W., W.A.T., R.P., M.T. and R.R.; investigation, A.M.-W., M.T, R.P., M.Ł., P.P. and M.C.; resources, A.M.W., and R.R.; data curation, A.M.-W., R.P. and W.A.T.; writing-original draft preparation, A.M-W., W.A.T., R.P. and M.T.; writing—review and editing, A.M.-W., W.A.T., R.P., R.R. and M.T.; visualization: R.P, W.A.T., and M.T.; supervision, A.M.-W., W.A.T., R.P. and R.R.; project administration, A.M.-W.; funding acquisition, A.M-W. and R.R. All authors have read and agreed to the published version of the manuscript.

Funding: This research was financially supported by the Foundation for Polish Science as part of the Parent-Bridge Programme, co-financed by the European Union from the European Regional Development Fund. The project "The role of tryptophan and its metabolites in physiology and pathology of ocular surface," agreement no. POMOST/2013-7/15, was carried out under the Innovative Economy Operational Programme ("IE OP"), Priority 1. Research and development of new technologies, Action 1.2. Strengthening the human resources potential of science, Parent-Bridge Programme. Monika Turska is a doctoral student at the Medical University of Lublin and the Postgraduate School of Molecular Medicine at the Medical University of Warsaw.

Institutional Review Board Statement: The study was conducted according to the guidelines of the Declaration of Helsinki and approved by the I Local Ethics Committee for Animal Experiments in Lublin, Medical University of Lublin, Poland (approval no. 27/2012).

Informed Consent Statement: All authors agreed with the content and that all gave explicit consent to submit and publish the results.

Data Availability Statement: Cell lines are available in ATCC. The rabbits came from a licensed farm in Chorzelów near Kraków, which is in the register of the Ministry of Science and Higher Education of Poland. The datasets generated during and/or analyzed during the current study are available from the author (Anna Matysik-Woźniak) on reasonable request.

Conflicts of Interest: The authors declare no conflict of interest.

\section{References}

1. Freire, V.; Andollo, N.; Etxebarria, J.; Hernáez-Moya, R.; Durán, J.A.; Morales, M.C. Corneal Wound Healing Promoted by 3 Blood Derivatives: An in Vitro and in Vivo Comparative Study. Cornea 2014, 33, 614-620. [CrossRef]

2. Geerling, G.; Daniels, J.T.; Dart, J.K.G.; Cree, I.A.; Khaw, P.T. Toxicity of Natural Tear Substitutes in a Fully Defined Culture Model of Human Corneal Epithelial Cells. Investig. Ophthalmol. Vis. Sci. 2001, 42, 948-956. [CrossRef]

3. Kim, T.H.; Park, Y.W.; Ahn, J.S.; Ahn, J.T.; Kim, S.E.; Jeong, M.B.; Seo, M.S.; Kang, K.S.; Seo, K.M. Effects of Conditioned Media from Human Amniotic Epithelial Cells on Corneal Alkali Injuries in Rabbits. J. Vet. Sci. 2013, 14, 61-67. [CrossRef]

4. Wirostko, B.; Rafii, M.; Sullivan, D.A.; Morelli, J.; Ding, J. Novel Therapy to Treat Corneal Epithelial Defects: A Hypothesis with Growth Hormone. Ocul. Surf. 2015, 13, 204-212. [CrossRef]

5. Livny, E.; Livnat, T.; Yakimov, M.; Masoud, M.; Weinberger, D.; Bahar, I. Effect of Erythropoietin on Healing of Corneal Epithelial Defects in Rabbits. Ophthalmic. Res. 2013, 50, 129-133. [CrossRef]

6. Matysik-Woźniak, A.; Paduch, R.; Turski, W.A.; Maciejewski, R.; Jünemann, A.G.; Rejdak, R. Effects of Tryptophan, Kynurenine and Kynurenic Acid Exerted on Human Reconstructed Corneal Epithelium in Vitro. Pharmacol. Rep. 2017, 69, 722-729. [CrossRef]

7. Matysik-Woźniak, A.; Turski, W.A.; Turska, M.; Paduch, R.; Łańcut, M.; Piwowarczyk, P.; Czuczwar, M.; Rejdak, R. Tryptophan as a Safe Compound in Topical Ophthalmic Medications: In Vitro and In Vivo Studies. Ocul. Immunol. Inflamm. 2021, 1-11. [CrossRef]

8. Liebig, J. Ueber Kynurensäure. Ann. Chem. Pharm. 1853, 86, 125-126. [CrossRef]

9. Matysik-Woźniak, A.; Wnorowski, A.; Draczkowski, P.; Jóźwiak, K.; Turski, W.; Augustyn, N.; Choragiewicz, T.; Rejdak, R. Tryptophan, Kynurenine and Kynurenic Acid in Human Tear Fluid. In Proceedings of the 8th International Symposium, CORNEA 2016, Wisla Poland, 3-5 March 2016; pp. 206-207.

10. Turski, M.P.; Turska, M.; Paluszkiewicz, P.; Parada-Turska, J.; Oxenkrug, G.F. Kynurenic Acid in the Digestive System-New Facts, New Challenges. Int. J. Tryptophan Res. 2013, 6, 13-15. [CrossRef]

11. Davis, I.; Liu, A. What Is the Tryptophan Kynurenine Pathway and Why Is It Important to Neurotherapeutics? Expert Rev. Neurother. 2015, 15, 719-721. [CrossRef] 
12. Matysik-Woźniak, A.; Jünemann, A.; Turski, W.A.; Wnorowski, A.; Jóźwiak, K.; Paduch, R.; Okuno, E.; Moneta-wielgoś, J.; Choragiewicz, T.; Maciejewski, R.; et al. The Presence of Kynurenine Aminotransferases in the Human Cornea: Evidence from Bioinformatics Analysis of Gene Expression and Immunohistochemical Staining. Mol. Vis. 2017, 23, 364-371. [PubMed]

13. Andine, P.; Lehmann, A.; Ellren, K. The Excitatory Amino Acid Antagonist Kynurenic Acid Administered after Hypoxic-Ischemia in Neonatal Rats Offers Neuroprotection. Neurosci. Lett. 1988, 90, 208-212. [CrossRef]

14. Stone, T.W.; Stoy, N.; Darlington, L.G. An Expanding Range of Targets for Kynurenine Metabolites of Tryptophan. Trends Pharmacol. Sci. 2013, 34, 136-143. [CrossRef]

15. Turski, M.P.; Kamiński, P.; Zgrajka, W.; Turska, M.; Turski, W.A. Potato-An Important Source of Nutritional Kynurenic Acid. Plant Foods Hum. Nutr. 2012, 67, 17-23. [CrossRef]

16. Resta, F.; Masi, A.; Sili, M.; Laurino, A.; Moroni, F.; Mannaioni, G. Kynurenic Acid and Zaprinast Induce Analgesia by Modulating HCN Channels through GPR35 Activation. Neuropharmacology 2016, 108, 136-143. [CrossRef]

17. Lucas, D.R.; Newhouse, J.P. The Toxic Effect of Sodium L-Glutamate on the Inner Layers of the Retina. Arch. Ophthalmol. 1957, 58, 193-201. [CrossRef] [PubMed]

18. Turski, G.N.; Ikonomidou, C. Glutamate as a Neurotoxin. In Handbook of Neurotoxicity; Springer: New York, NY, USA, 2014.

19. Ibitokun, B.O. Role of Glutamate in Corneal Nociception. Ph.D. Thesis, Oklahoma State University, Stillwater, OK, USA, 2012.

20. Zhao, P.; Lane, T.R.; Gao, H.G.L.; Hurst, D.P.; Kotsikorou, E.; Le, L.; Brailoiu, E.; Reggio, P.H.; Abood, M.E. Crucial Positively Charged Residues for Ligand Activation of the GPR35 Receptor. J. Biol. Chem. 2014, 289, 3625-3638. [CrossRef]

21. DiNatale, B.C.; Murray, I.A.; Schroeder, J.C.; Flaveny, C.A.; Lahoti, T.S.; Laurenzana, E.M.; Omiecinski, C.J.; Perdew, G.H. Kynurenic Acid Is a Potent Endogenous Aryl Hydrocarbon Receptor Ligand That Synergistically Induces Interleukin-6 in the Presence of Inflammatory Signaling. Toxicol. Sci. 2010, 115, 89-97. [CrossRef]

22. Matysik-Woźniak, A.; Wnorowski, A.; Turski, W.A.; Jóźwiak, K.; Jünemann, A.; Rejdak, R. The Presence and Distribution of G Protein-Coupled Receptor 35 (GPR35) in the Human Cornea-Evidences from in Silico Gene Expression Analysis and Immunodetection. Exp. Eye Res. 2019, 179, 188-192. [CrossRef]

23. Hu, H.H.; Deng, H.; Ling, S.; Sun, H.; Kenakin, T.; Liang, X.; Fang, Y. Integrative Biology. Integr. Biol. 2017, 9, 451-463. [CrossRef]

24. Choudhary, M.; Malek, G. The Aryl Hydrocarbon Receptor: A Mediator and Potential Therapeutic Target for Ocular and Non-Ocular Neurodegenerative Diseases. Int. J. Mol. Sci. 2020, 21, 6777. [CrossRef]

25. Poormasjedi-Meibod, M.S.; Hartwell, R.; Kilani, R.T.; Ghahary, A. Anti-Scarring Properties of Different Tryptophan Derivatives. PLoS ONE 2014, 9, 3. [CrossRef]

26. Oswald, D.J.; Lee, A.; Trinidad, M.; Chi, C.; Ren, R.; Rich, C.B.; Trinkaus-Randall, V. Communication between Corneal Epithelial Cells and Trigeminal Neurons Is Facilitated by Purinergic (P2) and Glutamatergic Receptors. PLoS ONE 2012, 7, e44574. [CrossRef] [PubMed]

27. Moroni, F.; Cozzi, A.; Mannaioni, G. Kynurenic Acid: A Metabolite with Multiple Actions and Multiple Targets in Brain and Periphery. J. Neural Transm. 2015, 119, 133-139. [CrossRef]

28. Zhang, L. Expression and Role of Aryl Hydrocarbon Receptor in Aspergillus Fumigatus Keratitis. Int. J. Ophthalmol. 2020, 13, 199. [CrossRef]

29. Ikuta, T.; Namiki, T.; Fujii-Kuriyama, Y.; Kawajiri, K. AhR Protein Trafficking and Function in the Skin. Biochem. Pharmacol. 2009, 77, 588-596. [CrossRef]

30. Flaveny, C.A.; Murray, I.A.; Perdew, G.H. Differential Gene Regulation by the Human and Mouse Aryl Hydrocarbon Receptor. Toxicol. Sci. 2010, 114, 217-225. [CrossRef]

31. Flaveny, C.; Reen, R.K.; Kusnadi, A.; Perdew, G.H. The Mouse and Human Ah Receptor Differ in Recognition of LXXLL Motifs. Arch. Biochem. Biophys. 2008, 471, 215-223. [CrossRef]

32. Tsukahara, T.; Hamouda, N.; Utsumi, D.; Matsumoto, K.; Amagase, K.; Kato, S. G Protein-Coupled Receptor 35 Contributes to Mucosal Repair in Mice via Migration of Colonic Epithelial Cells. Pharmacol. Res. 2017, 123, 27-39. [CrossRef]

33. Słoniecka, M.; le Roux, S.; Boman, P.; Byström, B.; Zhou, Q.; Danielson, P. Expression Profiles of Neuropeptides, Neurotransmitters, and Their Receptors in Human Keratocytes In Vitro and In Situ. PLoS ONE 2015, 10, 1-23. [CrossRef]

34. Wirthgen, E.; Hoeflich, A.; Rebl, A.; Günther, J. Kynurenic Acid: The Janus-Faced Role of an Immunomodulatory Tryptophan Metabolite and Its Link to Pathological Conditions. Front. Immunol. 2018, 8, 1957. [CrossRef] [PubMed]

35. Dua, H.S. The Conjunctiva in Corneal Epithelial Wound Healing. Br. J. Ophthalmol. 1998, 82, 1407-1411. [CrossRef] [PubMed]

36. Wilson, S.; Esposito, A. Focus on Molecules: Interleukin-1: A Master Regulator of the Corneal Response to Injury. Exp. Eye Res. 2009, 89, 124-125. [CrossRef] [PubMed]

37. Nishida, T.; Nakamura, M.; Mishima, H.; Otori, T.; Hikida, M. Interleukin 6 Facilitates Corneal Epithelial Wound Closure in Vivo. Arch. Ophthalmol. 1992, 110, 1292-1294. [CrossRef]

38. Arranz-Valsero, I.; Soriano-Romaní, L.; García-Posadas, L.; López-García, A.; Diebold, Y. IL-6 as a Corneal Wound Healing Mediator in an in Vitro Scratch Assay. Exp. Eye Res. 2014, 125, 183-192. [CrossRef]

39. Notara, M.; Shortt, A.; Galatowicz, G.; Calder, V.; Daniels, J. IL6 and the Human Limbal Stem Cell Niche: A Mediator of Epithelial-Stromal Interaction. Stem Cell Res. 2010, 5, 188-200. [CrossRef]

40. Ghasemi, H.; Ghazanfari, T.; Yaraee, R.; Owlia, P.; Hassan, Z.M.; Faghihzadeh, S. Roles of IL-10 in Ocular Inflammations: A Review. Ocul. Immunol. Inflamm. 2012, 20, 406-418. [CrossRef] 
41. Li, B.; Tian, L.; Diao, Y.; Li, X.; Zhao, L.; Wang, X. Exogenous IL-10 Induces Corneal Transplantation Immune Tolerance by a Mechanism Associated with the Altered Th1/Th2 Cytokine Ratio and the Increased Expression of TGF- $\beta$. Mol. Med. Rep. 2014, 9, 2245-2250. [CrossRef]

42. Csáti, A.; Edvinsson, L.; Vécsei, L.; Toldi, J.; Fülöp, F.; Tajti, J.; Warfvinge, K. Kynurenic Acid Modulates Experimentally Induced Inflammation in the Trigeminal Ganglion. J. Headache Pain 2015, 16, 1-14. [CrossRef]

43. Körtési, T.; Tuka, B.; Tajti, J.; Bagoly, T.; Fülöp, F.; Helyes, Z.; Vécsei, L. Kynurenic Acid Inhibits the Electrical Stimulation Induced Elevated Pituitary Adenylate Cyclase-Activating Polypeptide Expression in the TNC. Front. Neurol. 2018, 8, 745. [CrossRef]

44. Lukacs, M.; Tajti, J.; Fulop, F.; Toldi, J.; Edvinsson, L.; Vecsei, L. Migraine, Neurogenic Inflammation, Drug DevelopmentPharmacochemical Aspects. Curr. Med. Chem. 2017, 24, 3649-3665. [CrossRef]

45. Poormasjedi-Meibod, M.-S.; Pakyari, M.; Jackson, J.K.; Salimi Elizei, S.; Ghahary, A. Development of a Nanofibrous Wound Dressing with an Antifibrogenic Properties in Vitro and in Vivo Model. J. Biomed. Mater. Res. Part A 2016, 104, 487-497. [CrossRef]

46. Toh, Z.H.; Lee, C.S.Y.; Chew, A.C.Y.; Perera, S. Time Heals All Wounds: Obstacles in Glaucoma Surgery from an Asian Perspective. Proc. Singap. Healthc. 2015, 24, 103-112. [CrossRef]

47. Wejksza, K.; Rzeski, W.; Turski, W.A. Kynurenic Acid Protects against the Homo-Cysteine-Induced Impairment of Endothelial Cells. Pharmacol. Rep. 2009, 61, 751-756. [CrossRef]

48. Rödl, J.B.; Bleich, S.; Schlötzer-Schrehardt, U.; Von Ahsen, N.; Kornhuber, J.; Naumann, G.O.; Kruse, F.E.; Jünemann, A.G. Increased Homocysteine Levels in Tear Fluid of Patients with Primary Open-Angle Glaucoma. Ophthalmic Res. 2008, 40, 249-256. [CrossRef] [PubMed]

49. Ajith, T.A. Ranimenon Homocysteine in Ocular Diseases. Clin. Chim. Acta 2015, 450, 316-321. [CrossRef] [PubMed]

50. Papp, A.; Hartwell, R.; Evans, M.; Ghahary, A. The Safety and Tolerability of Topically Delivered Kynurenic Acid in Humans. A Phase 1 Randomized Double-Blind Clinical Trial. J. Pharm. Sci. 2018, 107, 1572-1576. [CrossRef]

51. Samanta, A.; Guchhait, N.; Bhattacharya, S.C. Photophysical Aspects of Biological Photosensitizer Kynurenic Acid from the Perspective of Experimental and Quantum Chemical Study. Spectrochim. Acta Part A Mol. Biomol. Spectrosc. 2014, 129, 713-715. [CrossRef]

52. Zhuravleva, Y.S.; Sherin, P.S. Influence of PH on Radical Reactions between Kynurenic Acid and Amino Acids Tryptophan and Tyrosine. Part, I. Amino Acids in Free State. Free. Radic. Biol. Med. 2021, 172, 331-339. [CrossRef]

53. Zelentsova, E.A.; Sherin, P.S.; Snytnikova, O.A.; Kaptein, R.; Vauthey, E.; Tsentalovich, Y.P. Photochemistry of Aqueous Solutions of Kynurenic Acid and Kynurenine Yellow. Photochem. Photobiol. Sci. 2013, 12, 546-558. [CrossRef]

54. Zarnowski, T.; Rejdak, R.; Zagorski, Z.; Juenemann, A.G.M.; Zrenner, E.; Kocki, T.; Urbanska, E.M.; Turski, W.A. Content of Kynurenic Acid and Activity of Kynurenine Aminotransferases in Mammalian Eyes. Ophthalmic Res. 2004, 36, 124-128. [CrossRef]

55. Flieger, J.; Święch-Zubilewicz, A.; Śniegocki, T.; Dolar-Szczasny, J.; Pizoń, M. Determination of Tryptophan and Its Major Metabolites in Fluid from the Anterior Chamber of the Eye in Diabetic Patients with Cataract by Liquid Chromotography Mass Spectrometry (LC-MS/MS). Molecules 2018, 23, 3012. [CrossRef]

56. Moshirfar, M.; Chew, J.; Werner, L.; Meyer, J.J.; Hunter, B.; Stevens, S.; Jensen, M.; Kleinmann, G.; Mamalis, N. Comparison of the Effects of Fourth-Generation Fluoroquinolones on Corneal Re-Epithelialization in Rabbit Eyes. Graefe's Arch. Clin. Exp. Ophthalmol. 2008, 246, 1455-1461. [CrossRef]

57. Tetz, M.R.; Auffarth, G.U.; Sperker, M.; Blum, M.; Völcker, H. Photographic Image Analysis System of Posterior Capsule Opacification. J. Cataract Refract. Surg. 1997, 23, 1351-1355. [CrossRef] 